\title{
Bimbingan Membaca Al-Qur'an Melalui Metode Iqra' pada Anak Masa Kini di Panti Asuhan Yayasan Bani Adam 'As Medan
}

\section{Hairani Siregar*1, Mhd. Farhan Shidqi Tanjung²}

\author{
1,2Jurusan Kesejahteraan Sosial, Fakultas Ilmu Sosial dan Ilmu Politik, Universitas Sumatera Utara, \\ Indonesia \\ *e-mail: hairani_fisipusu@yahoo.co.id1ㅜㄹ farhantanjung10@gmail.com²
}

\begin{abstract}
Abstrak
Memberikan pengajaran tentang pentingnya membaca Al-Qur'an pada anak masa kini bukan hal yang mudah, karena selain memerlukan pengetahuan seorang tenaga didik juga harus mengetahui metode yang dapat dipakai dalam proses pembelajaran. Penelitian ini bertujuan untuk mengetahui penerapan metode iqra' sebagai kemampun dasar membaca Al-Qur'an anak masa kini khususnya di Panti Asuhan Yayasan Bani Adam 'As Kota Medan. Penelitian atau praktikum ini menggunakan intervensi komunitas yang dikemukakan oleh Zastrow, sebagai berikut; Intake, Assesment, Perencanaan Intervensi, Penyeleksian Anggota, Pengembangan Kelompok, Evaluasi dan Terminasi. Dari hasil penelitian atau praktikum ini, diharapkan adanya peningkatan kemampuan membaca Al-Qur'an melalui metode Iqra' pada anak masa kini khususnya di Yayasan Panti Asuhan Bani Adam As. Selain itu, program ini juga memberikan manfaat pada mental spiritual anak yang artinya pelaksanaan ini besar harapan agar memberikan dampak positif.
\end{abstract}

Kata kunci: Al-Qur'an, Metode Iqra', Penerapan

\begin{abstract}
Teaching about the importance of reading the Qur'an to children today is not easy, because in addition to requiring knowledge a student must also know the methods that can be used in the learning process. This research aims to find out the application of iqro method 'As a basis for reading the Qur'an of today's children, especially in the Orphanage of the Bani Adam 'As Foundation Medan City. This research or practicum uses community interventions put forward by Zastrow, as follows; Intake, Assessment, Intervention Planning, Member Selection, Group Development, Evaluation and Termination. From the results of this research or practicum, it is expected that there will be an increase in the ability to read the Qur'an through iqra' method in today's children, especially in the Bani Adam 'As Orphanage Foundation. In addition, this program also provides benefits to the child's spiritual mentality which means that the implementation is great hope to have a positive impact.
\end{abstract}

Keywords: Al-Qur'an, Application, Iqra' Method

\section{PENDAHULUAN}

Pendidikan hendaklah dilakukan sejak dini dapat dilakukan di dalam keluarga, sekolah, maupun masyarakat. Berbagai hasil para pakar kejiwaan mengatakan bahwa perawatan anak usia dini dalam keluarga mempunyai pengaruh besar di kemudian hari. Pendidikan anak usia dini adalah suatu proses pembinaan dan perkembangan jasmani dan rohani agar anak memiliki kesiapan rangsangan dalam memasuki pendidikan lebih lanjut (Boediono dkk, 2003). Pendidikan merupakan bimbingan secara sadar oleh seorang guru terhadap perkembangan jasmani dan rohani anak didik menuju terbentuknya kepribadian utama. (Marimba, 2009).

Perkembangan teknologi dan informasi dalam era globalisasi membawa pengaruh perubahan yang signifikan dalam membentuk watak dan kepribadian seseorang, baik pengaruh positif maupun pengaruh negatif kepada anak khususnya pada anak usia dini yang lebih cepat mencontoh. Dunia pendidikan mempunyai tantangan yang sangat berat karena dituntut untuk dapat melahirkan manusia-manusia yang tidak hanya mampu menguasai teknologi dan informasi agar dapat bersaing di dunia internasional akan tetapi juga menjadi manusia yang beradab.

Kemajuan peradaban suatu bangsa pada hakikatnya dimulai dari pengembangan di bidang pendidikan. Hal ini ditandai dengan turunnya firman Allah SWT yang pertama dalam Al- 
Qur'an surat Al-'Alaq (96:1-5) yaitu:

Bacalah dengan (menyebut) nama Tuhan-mu yang menciptakan, Dia telah menciptakan manusia dari segumpal darah. Bacalah, dan Tuhanmu-lah Yang Mahamulia, Yang mengajar (manusia) dengan pena, Dia mengajar manusia apa yang tidak diketahuinya (Depag, 2007).

Allah SWT telah mengisyaratkan kepada seluruh umat manusia untuk banyak belajar berbagai hal untuk dapat membaca tanda-tanda kekuasaan Allah SWT yang ada dalam kehidupan, karena dengan membaca tentunya banyak menemukan hal-hal baru yang sangat bermanfaat sebagai bekal hidup di dunia dan di akhirat (Zulfitria, 2017).

Pendidikan memegang peranan yang sangat penting dalam peningkatan kualitas sumber daya manusia dalam sebuah negara. Pendidikan merupakan suatu hal yang mutlak harus dipenuhi dalam upaya meningkatkan taraf hidup bangsa Indonesia agar tidak sampai tertinggal dengan bangsa lain. Hal ini tercantum dalam Undang-Undang Pendidikan Nasional Nomor 20 Tahun 2003, tentang Sistem Pendidikan Nasional berbunyi sebagai berikut: "pendidikan adalah usaha sadar dan terencana untuk mewujudkan suasana belajar dan proses pembelajaran agar peserta didik secara aktif mengembangkan potensi dirinya untuk memiliki kekuatan spritual keagamaan, pengendalian diri, kepribadian, kecerdasan, akhlak mulia, serta keterampilan yang diperlukan dirinya, masyarakat, bangsa dan negara" (Sisdiknas, 2003).

\section{METODE}

Dalam upaya agar tercapainya tujuan dari mini project tersebut, adapun beberapa tahapan intervensi komunitas seperti halnya menurut pandangan Zastrow yaitu, sebagai berikut:

a. Tahap Intake: yang diawali dengan adanya pengakuan mengenai masalah yang mungkin dapat dipecahkan melalui pendekatan kelompok. Dalam tahap ini perlu dilakukannya perumusan, persetujuan dan komitmen antara seorang pekerja sosial dengan klien untuk melakukan kegiatan-kegiatan melalui kelompok.

b. Tahap Assesment dan Perencanaan Intervensi: pada tahap ini, Farhan bersama anggota kelompok mengidentifikasi masalah, tujuan yang hendak dicapai dan merencanakan tindakan-tindakan pemecahan masalah dalam kelompok tersebut. Tools Assesment yang digunakan adalah FGD (Focus Group Discussion) guna mengumpulkan kelompok dan membahas topik yang telah ditentukan. Akan tetapi, pada tahap ini diperlukan Teori kognitif yaitu teori yang mengatakan bahwa belajar merupakan suatu proses perubahan presepsi dan pemahaman yang dapat diukur serta diamati. Model ini lebih berorientasi pada studi tentang bagaimana seorang siswa belajar untuk berfikir. Fokus studiya ialah pada pertanyaan perkembangan kognitif. Bagi guru yang terpenting adalah bagaimana dapat mempengaruhi perkembangan pola fikir dan juga bagaimana dapat menyesuaikan pengajaran dengan tingkat perkembangan kognitif para siswa.

c. Tahap Penyeleksian Anggota: dalam tahap penyeleksian anggota, Farhan menyeleksi anggota berdasarkan usia mereka. Hal ini dilakukan untuk mengelompokkan anak-anak panti agar dapat menerima pembelajaran sesuai dengan kemampuan mereka.

d. Tahap Pengembangan Kelompok: pada tahap ini Farhan melakukan peranan yang aktif dalam memotivasi kelompok guna mencapai tujuan yang telah disepakati.

e. Tahap Evaluasi dan Terminasi: pada tahap evaluasi, Farhan mengkaji kembali program yang telah ditetapkan dan juga mengetahui apakah hasil dari program tersebut sudah sesuai dengan tujuan yang dibuat atau belum. Kemudian, pada tahap terminasi yaitu dimana tujuan yang direncanakan sudah tercapai sehingga dapat menyelesaikan kontrak.

\section{HASIL DAN PEMBAHASAN}

\subsection{Survei Pendahuluan dan Persiapan Materi Kegiatan}

Survei Pendahuluan ini pada awalnya dilaksanakan pada tanggal 4 September $2021 \mathrm{di}$ 
Panti Asuhan Bani Adam 'As Medan yang beralamat di Pasar 2 Jl. Mangaan III Ps. II No. 216 MABAR, Kecamatan Medan Deli, Kota Medan, Sumatera Utara. Kegiatan ini bertujuan untuk menanyakan ketersediaan pengelola Panti Asuhan terhadap kegiatan pengabdian masyarakat. Setelah itu, diperoleh kesepakatan bahwa akan diadakannya kegiatan pengabdian masyarakat kurang lebih selama 3 bulan, dimulai dari bulan September 2021 sampai awal bulan Desember 2021.

\subsection{Sosialisasi dan Kegiatan Bimbingan Belajar}

Kegiatan sosialisasi dan bimbingan belajar Iqra' yang dilakukan di Panti Asuhan Bani Adam As. dilakukan selama seminggu tiga kali terhitung dari tanggal 10 September 2021. Pelatihan kegiatan mengenai membaca Al-Qur'an melalui metode Iqra' dihadiri oleh 5-10 orang anak panti asuhan tersebut.

Kegiatan awalnya bermula dari sosialisasi mengenai pentingnya mengetahui huruf hijaiyah serta menjelaskan alasan-alasan yang menarik untuk belajar dengan metode Iqra' yang bertujuan untuk menarik antusias anak panti. Kemudian, terdapat kegiatan tambahan yang dilaksanakan selama masa praktikum ini adalah edukasi, belajar dan juga bermain hal ini untuk menghindari anak-anak panti merasa jenuh serta bosan dengan proses pembelajaran yang dilakukan.

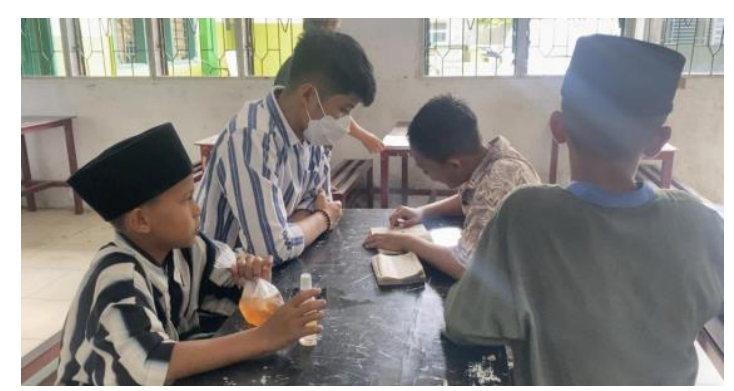

Gambar 1. Proses Pembelajaran Metode Iqra'

Kegiatan ini dievaluasi berdasarkan ketercapaian tujuan kegiatan, yang mana kegiatan ini bertujuan untuk mengetahui capaian keberhasilan peserta dalam memahami materi yang diberikan, dan juga untuk melihat kesesuaian materi dengan kemampuan peserta kegiatan. Evaluasi dilaksanakan dengan tujuan untuk melihat tingkat keberhasilan peserta mengenal huruf hijaiyah dalam pelaksanaan kegiatan pelatihan, selain itu juga untuk memantau proses jalannya program, dan keefektifan proses kegiatan. Hasil dari kegiatan yang dilakukan adalah terjadi peningkatan keterampilan membaca serta motivasi mereka dalam belajar Iqra'. Artinya terdapat dampak positif yang signifikan setelah pelaksanaan program ini.

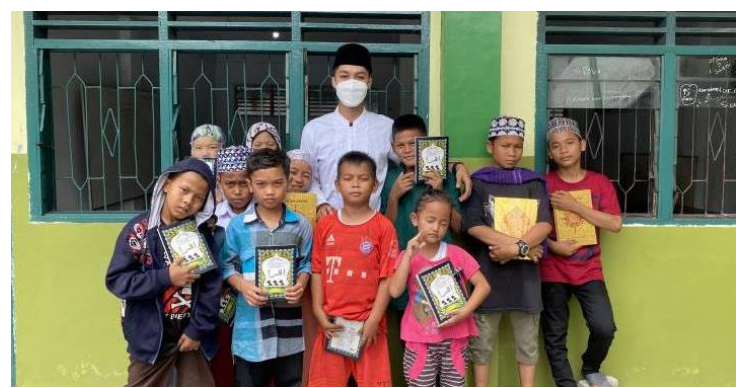

Gambar 2. Pembagian Iqra' dan Al-Quran

Dari penjelasan diatas berdasarkan evaluasi, didapatkan hasil: (1) Peserta pelatihan sangat antusias mengikuti kegiatan pelatihan, terlihat dengan hasil latihan dan praktik yang menunjukkan adanya peningkatan pemahaman dan keterampilan dalam membaca Iqra', (2) bertambahnya minat mereka dalam mempelajari Iqra' yang terlihat dari keaktifan mereka dalam melakukan praktik, serta kehadiran jumlah peserta yang tidak berkurang, yaitu sebanyak 10 
orang, (4) peserta pelatihan merasa terbantu dengan adanya kegiatan tambahan praktik membaca Iqra' ini.

Pengumpulan data yang dipakai dalam kegiatan ini adalah: (1) soal tes membaca, digunakan untuk melihat kelancaran membaca para peserta. Tes dikerjakan peserta secara individual yang diberikan di akhir materi pembelajaran, dan (2) catatan lapangan, dilakukan dengan mendokumentasikan proses pembelajaran membaca Iqra' dan foto kegiatan selama proses mengajar.

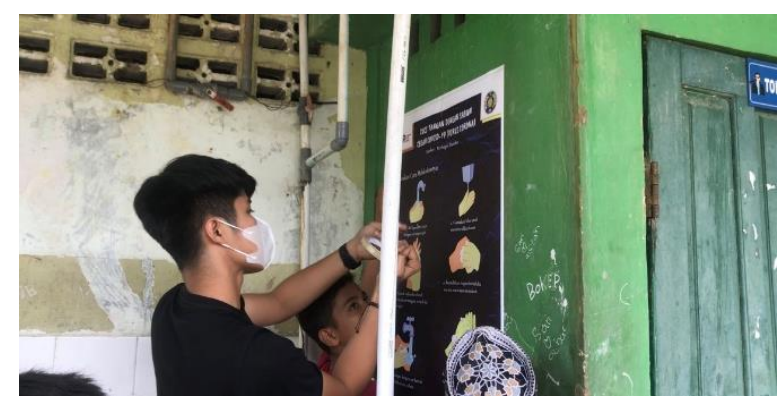

Gambar 3. Penempelan Poster.

Tidak hanya memberikan sosialisasi dan kegiatan tentang metode pembelajaran Iqra', penulis juga memberikan praktik mencuci tangan yang benar serta membagikan masker. Setelah itu, mendesain dan menempelkan poster bertemakan pentingnya mencuci tangan dengan sabun turut mengiisi agenda pada kegiatan ini.

\section{KESIMPULAN}

Kegiatan ini meliputi penyampaian materi, diskusi kelas, diskusi kelompok. Berdasarkan kegiatan yang telah dilaksanakan, maka dapat ditarik kesimpulan bahwa terjadi peningkatan keterampilan membaca Iqra'. Dan dari hasil observasi, selama kegiatan pendampingan berlangsung, peserta antusias dan semakin termotivasi untuk membaca Iqra'. Dengan kegiatan ini diharapkan kemampuan peserta dalam belajar membaca Iqra' semakin meningkat sehingga bisa mereka manfaatkan dimasa yang akan datang.

\section{UCAPAN TERIMA KASIH}

Ucapan terima kasih disampaikan kepada Pengelola Panti Asuhan Bani Adam As, Bapak Bona yang telah banyak membantu penulis dalam kegiatan ini, serta menerima penulis layaknya seperti saudara sendiri. Serta anak-anak yang berada di Yayasan Panti Asuhan Bani Adam As. Kota Medan yang menyambut dengan ramah dan hangat sehingga kegiatan yang dilakukan dapat berjalan dengan baik dan lancar. Harapannya semoga kita semua selalu dalam lindungan Allah Swt.

\section{DAFTAR PUSTAKA}

Marimba, Ahmad D. (2009). Pengantar Filsafat Pendidikan Islam. Bandung : Al- Maarif.

Boediono, ed., (2003). Standar Kompetensi Pendidikan Anak Usia Dini Taman Kanak-Kanak dan Raudhatul Athfal. Jakarta: Departemen Pendidikan Nasional.

Departemen Agama RI. (2007). Al- Qur'anulkarim Terjemahan Perkata. Bandung: Syaamil AlQur'an.

Diknas. Undang-Undang Republik Indonesia Nomor 20 Tahun 2003 Tentang Sistem Pendidikan Nasional, Pasal 1, ayat 1. 